\title{
Formation of Factor $\mathrm{V}_{\mathrm{a}}$ by Atherosclerotic Rabbit Aorta Mediates Factor $\mathbf{X}_{\mathbf{a}}$-catalyzed Prothrombin Activation
}

\author{
George M. Rodgers, „* William H. Kane, ${ }^{3}$ and Robert E. Pitas*\|l \\ *Gladstone Foundation Laboratories for Cardiovascular Disease, Cardiovascular Research Institute; "Department of Pathology, \\ University of California, San Francisco, California 94140-0608; ${ }^{\ddagger}$ Cancer Research Institute, \\ Departments of Medicine and Laboratory Medicine, University of California, San Francisco, California 94143; \\ and ${ }^{\S}$ Department of Biochemistry, University of Washington, Seattle, Washington 98195
}

\begin{abstract}
Vascular cell procoagulant activity may be important in the pathogenesis of atherosclerosis. In previous studies, we described the ability of the atherogenic metabolite homocysteine to activate endothelial cell Factor $V$, a key coagulation cofactor for thrombin generation. The present study was designed to investigate Factor $V$ activity and Factor $X_{\mathrm{a}}$-catalyzed prothrombin activation by control and atherosclerotic aorta from normal and hypercholesterolemic rabbits. Factor $\mathbf{X}_{\mathbf{a}}$ generated ninefold more thrombin on atherosclerotic aortic segments than on control segments. Atherosclerotic segments activated ${ }^{125} I$-prothrombin with Factor $X_{a}$ in the presence of the thrombin inhibitor dansyl arginine-4-ethylpiperidine amide and cleaved ${ }^{125} I$-Factor $V$. This suggests that increases in vessel-wall Factor $V$ activity and Factor $X_{a}$-catalyzed prothrombin activation result from activation of vessel-wall Factor $V .{ }^{125} I-$ Factor $V_{a}$ peptides generated by atherosclerotic aorta were very similar in molecular weight to those generated by homocysteine-treated cells. When vascular endothelium was mechanically removed by brushing, atherosclerotic vessels still generated four- to fivefold more thrombin than control vessels. These data and results from immunocytochemical studies suggest that Factor $\mathrm{V}$ in atherosclerotic vessels is associated with both endothelium and other cells of the lesion. In contrast, Factor $\mathbf{V}$ in control vessels is associated primarily with endothelium. The increases in Factor $V$ activity and thrombin formation in the blood vessel wall of hypercholesterolemic rabbits may contribute to the development of atherosclerosis and its complications.
\end{abstract}

\section{Introduction}

Endothelial cell injury is postulated to initiate atherosclerosis (1). Two conditions associated with atherosclerotic vascular disease are elevated serum levels of cholesterol (2) or homocysteine (3). In a previous study, we reported that homocysteine-treated endothelial cells exhibited increased procoagulant activity (4) as a result of activation of endogenous Factor V. Factor $V_{a}$ associated with cellular surfaces serves as the

Address all correspondence to Dr. George M. Rodgers, Division of Hematology-Oncology, University of Utah Medical Center, Salt Lake City, UT 84132.

Received for publication 27 April 1987 and in revised form 23 November 1987.

J. Clin. Invest.

(C) The American Society for Clinical Investigation, Inc.

$0021-9738 / 88 / 06 / 1911 / 09 \$ 2.00$

Volume 81, June 1988, 1911-1919 receptor for Factor $\mathrm{X}_{\mathrm{a}}$; formation of the Factor $\mathrm{V}_{\mathrm{a}}-$ Factor $\mathbf{X}_{\mathrm{a}}$ complex results in the activation of prothrombin to the coagulation protease thrombin (5). The ability of perturbed endothelial cells to activate this important coagulation cofactor resulted in enhanced Factor $\mathbf{X}_{\mathrm{a}}$-catalyzed prothrombin activation and increased generation of thrombin (4). Thrombin formation is important, not only in the generation of fibrin, but also in the amplification of the coagulation mechanism (6).

These data led us to consider whether hypercholesterolemia would induce similar changes in vascular procoagulant activity, since exposure of endothelium to high concentrations of atherogenic lipoproteins (modified LDL and $\beta$-VLDL) results in abnormal endothelial cell morphology $(7,8)$. In fact, specific receptors for modified LDL (9) and $\beta$-VLDL (10) have been identified on cultured endothelium. Perturbation of endothelial cells by other stimuli, including endotoxin (11) and IL-1 (12), has been demonstrated to induce expression of procoagulant (tissue factor) activity. Expression of vascular procoagulant activity may, therefore, occur in hypercholesterolemia, leading to thrombin generation. Thrombin has been demonstrated to cause monocyte chemotaxis (13) and mitogenesis (14), endothelial cell retraction (15), and release of endothelial cell mitogens (16), events that could be involved in atherogenesis. Thus, thrombin may contribute to the development of the atherosclerotic lesion.

One approach to the study of atherogenic stimuli and endothelial cell procoagulant properties is to use an animal model of atherosclerosis. Although there are limitations in extrapolating from data obtained in these in vivo models to human atherosclerosis, certain animal models of hyperlipidemia have provided important information relevant to the human form of this disorder $(1,17-20)$. In this study, we used a rabbit model of diet-induced atherosclerosis to investigate vessel-wall procoagulant properties. In particular, Factor $\mathrm{V}$ activity and Factor $\mathrm{X}_{\mathrm{a}}$-catalyzed prothrombin activation in thoracic aorta from control and hypercholesterolemic animals were examined. These coagulant properties were previously noted to be enhanced after in vitro exposure of endothelial cells to the atherogenic stimulus homocysteine (4). The data demonstrate that vessel segments from hypercholesterolemic animals exhibit increased Factor $\mathrm{V}$ activity and enhanced Factor $\mathrm{X}_{\mathrm{a}}$-catalyzed prothrombin activation. This procoagulant activity results primarily from induction of a vessel-wall activator of Factor V.

\section{Methods}

Materials. Trizma base, BSA (RIA grade), Russell's Viper venom, Protein A-Sepharose, and plasmas deficient in Factors VII-X and Factor V were obtained from Sigma Chemical Co. (St. Louis, MO). Sodium [ $\left.{ }^{125} \mathrm{I}\right]$ iodide was obtained from Amersham Corp. (Clearbrook, 
IL). Iodogen was supplied by Pierce Chemical Co. (Rockford, IL). DME and other reagents for cell culture were obtained from the University of California, San Francisco Cell Culture Facility and had $<10$ $\mathrm{pg}$ of endotoxin/ml. Calf serum was supplied by HyClone Laboratories, Inc. (Logan, UT). The thrombin inhibitor, dansyl arginine-4-ethylpiperidine amide (DAPA)', was provided by Dr. Philip Majerus (Washington University, St. Louis, MO). A human anti-Factor V IgG was prepared from the plasma of a patient with an acquired antibody. The IgG was isolated from plasma using a Protein A-Sepharose affinity column. This IgG $(100 \mu \mathrm{g})$ could neutralize $95 \%$ of the coagulant activity of $1 \mu \mathrm{g}$ of purified human plasma Factor $\mathrm{V}$ after a 2-h incubation at $37^{\circ} \mathrm{C}$. Immunocytochemical studies to detect Factor $V$ in atherosclerotic lesions were performed using this anti-human Factor $\mathrm{V}$ IgG and a Vectastain kit (Vector Laboratories, Inc., Burlingame, CA). Adult bovine aortic endothelial (ABAE) cells were cultured as previously described (4).

Factor $\mathrm{X}$ and prothrombin were purified from human plasma as described (21). Human Factor $V$ was purified according to the methods of Kane and Majerus (22). Bradford's technique was followed to assay protein concentrations (23). Prothrombin and Factor $V$ were iodinated using the Iodogen technique (22). Standard clotting assays were used to measure Factor $X$ activity (24), and Factor $X$ was activated using Russell's Viper venom coupled to Sepharose (25). Normal rabbit plasma was obtained by venipuncture using an anticoagulant solution containing $3.8 \%$ sodium citrate, $10 \mathrm{mM}$ benzamidine, and 0.1 mM PMSF.

Hypercholesterolemic rabbit model. Male New Zealand White rabbits (3-3.5 kg) were fed either a standard diet (control: rabbit chow, Zeigler Brothers, Inc., Gardners, PA) or an atherogenic diet containing $0.5 \%$ cholesterol (NIH Zeigler 700-79) for 12-16 wk (26). 10 control rabbits and 10 rabbits on the high-cholesterol diet for this period were studied. Aortas from control and hypercholesterolemic rabbits were obtained after anesthesia and exsanguination. Atherosclerotic aorta generally exhibited diffuse fatty streak lesions, and the involved thoracic segments were taken for assay. Control segments were taken from similar locations of normal aorta. The vessels were placed in warmed, sterile DME containing $1 \%$ BSA.

Vessel-wall coagulation assays. Coagulant properties of the vessels were assessed using a Lucite template device (exposed vessel surface area $\sim 0.75 \mathrm{~cm}^{2}$ ), similar to that previously used by our laboratory to study prothrombin activation by bovine vessels and Factor $X_{a}(27)$. In this prothrombin activation assay, the following additions were made to the template well: $0.4 \mathrm{ml}$ of warmed $20 \mathrm{mM}$ Tris- $\mathrm{HCl}, 150 \mathrm{mM}$ $\mathrm{NaCl}$ (Tris-buffered saline [TBS]), pH 7.4; $35 \mu \mathrm{g}$ of purified prothrombin; and $0.05 \mathrm{ml}$ of $100 \mathrm{mM} \mathrm{CaCl}$. The reaction was initiated by adding $10 \mathrm{ng}$ of Factor $\mathrm{X}_{\mathrm{a}}$. Total reaction volume was $0.5 \mathrm{ml}$. At intervals, aliquots were removed for thrombin assay (28). Replicate values obtained by this assay varied by $\pm 10 \%$ (SEM).

To determine whether vascular tissue not exposed to template manipulation had similar coagulant properties, aortic arches were obtained from control and hypercholesterolemic rabbits. These segments were gently washed with medium to remove blood. The major blood vessels originating from the aortic arch and the root of the aorta were ligated to form a small pouch $\sim 1-1.5 \mathrm{~cm}$ long. Prothrombin activation by these vessels and Factor $X_{\mathbf{a}}$ was assayed in the vessel segment by using $20 \%$ of the amounts of the components listed above; total volume was $0.1 \mathrm{ml}$. Thus, similar concentrations of reactants were used in studies with the template device and with aortic pouches.

Immunocytochemical techniques. Cross-reactivity between the anti-human Factor V IgG and rabbit Factor V was demonstrated by immunoblotting (29). Purified human Factor $\mathrm{V}$ and normal rabbit plasma were subjected to 5\% nonreduced SDS-PAGE. Separated proteins were transferred to nitrocellulose filter paper. The total protein

1. Abbreviations used in this paper: $\mathrm{ABAE}$, adult bovine aortic endothelial cells; DAPA, dansyl arginine-4-ethylpiperidine amide; PDGF, platelet-derived growth factor; TBS, Tris-buffered saline. was then visualized with Ponceau S (30). In a duplicate blot, Factor V was detected using the anti-human Factor V IgG and an ${ }^{125} \mathrm{I}$-labeled second antibody. Visualization was by autoradiography.

The presence of Factor $\mathrm{V}$ in aorta from control and hypercholesterolemic rabbits was examined by peroxidase immunocytochemistry as described previously (31). $2-\mathrm{mm}^{2}$ segments of aorta were fixed for 4 $\mathrm{h}$ at $4^{\circ} \mathrm{C}$ with freshly prepared $4 \%$ formaldehyde in $0.15 \mathrm{M}$ phosphate buffer, $\mathrm{pH} 7.4$, and then infiltrated for $12 \mathrm{~h}$ with $18 \%$ sucrose in PBS. The tissue was then frozen in isobutane cooled with liquid nitrogen. 6-8- $\mu \mathrm{m}$ frozen sections were processed for immunocytochemical examination on gelatin-coated slides (31). $0.15 \%$ Triton X-100 was included in the initial blocking solution to make the cells more permeable. The primary antibody was human anti-human Factor V IgG. This antibody cross-reacted with rabbit Factor V. In control experiments in which the solution that contained the primary antibody was incubated with authentic human Factor $V$, reactivity with the rabbit aortic segments was completely blocked.

In certain experiments, endothelial cells were removed from aortic segments to determine the contribution of these cells to overall vesselwall Factor V activity. Endothelium was removed by brushing the intimal surface with a moist camel-hair brush and rinsing the segment with PBS. Removal of 95\% of the endothelial cells was confirmed by light-level microscopy of the plastic-embedded sections (32).

Assays of Factor $V\left(V_{a}\right)$ activity. Factor $\mathrm{V}\left(\mathrm{V}_{\mathrm{a}}\right)$ activity of control and atherosclerotic aortic segments was measured by freeze-thawing $\sim 1-\mathrm{cm}^{2}$ punch biopsy samples of the vessel wall in $0.5 \mathrm{ml}$ of TBS, followed by assay of Factor $V$ activity using a clotting technique (33). Factor $\mathrm{V}$ activity was expressed as $\mathrm{mU} / \mu \mathrm{g}$ of protein; $1 \mathrm{U}$ of Factor $\mathrm{V}$ activity is equivalent to that present in $1 \mathrm{ml}$ of pooled human plasma.

Two methods were used to determine whether atherosclerotic vessel segments contained Factor $\mathrm{V}_{\mathrm{a}}$ activity. In the first method, cleavage of ${ }^{125} \mathrm{I}$-prothrombin by Factor $\mathrm{X}_{\mathrm{a}}$ and either control or hypercholesterolemic aortic segments was determined in the presence or absence of the thrombin inhibitor DAPA $(100 \mu \mathrm{M})$. The rationale for these experiments is that Factor $X_{a}$ cannot cleave ${ }^{125} I$-prothrombin in the presence of a thrombin inhibitor unless Factor $\mathrm{V}$ has been activated. $\sim 1-\mathrm{cm}^{2}$ vessel segments were incubated in $0.5 \mathrm{ml}$ of culture medium that contained $30 \mu \mathrm{g}$ of ${ }^{125} \mathrm{I}$-prothrombin. After addition of $10 \mathrm{ng}$ of Factor $\mathrm{X}_{\mathrm{a}}$, aliquots of the incubation were removed at intervals, subjected to nonreduced SDS-PAGE, dried, and processed for autoradiography (25) to determine the extent of ${ }^{125} \mathrm{I}$-prothrombin cleavage.

The second method was used to determine whether atherosclerotic vessel segments were able to activate exogenous Factor V. $300 \mathrm{ng}$ of freshly prepared ${ }^{125} \mathrm{I}$-Factor $\mathrm{V}$ was added to $\sim 1-\mathrm{cm}^{2}$ control or hypercholesterolemic aortic segments in $0.5 \mathrm{ml}$ of DME-BSA. At intervals, the medium was removed and $0.1 \mathrm{ml}$ of reduced SDS-gel buffer was added to the segments. Solubilized material associated with the vessel segments was analyzed by reduced SDS-PAGE and autoradiography.

Lipoprotein studies. Human LDL was isolated from normal plasma as described (34), and the lysine residues were modified by acetoacetylation with diketene (35). Hyperlipoproteinemic plasma was obtained from cholesterol-fed rabbits for isolation of $\beta$-VLDL (35). To determine whether purified lipoproteins could affect Factor $V$ activity of cultured endothelial cells, purified native and modified lipoproteins were incubated with confluent ABAE cells for 3-48 h in serum-free medium. The cells were processed as described for determination of Factor V activity (4).

\section{Results}

Factor $X_{a}$-catalyzed prothrombin activation by atherosclerotic aorta. Rabbits that had been fed a diet containing $0.5 \%$ cholesterol for 12-16 wk were routinely studied. As a result of this diet, serum cholesterol levels were $>1,000 \mathrm{mg} / \mathrm{dl}$ at this time, and typical fatty streak atherosclerotic lesions of the aorta were grossly visible. In contrast, serum cholesterol levels in control 
rabbits were $<100 \mathrm{mg} / \mathrm{dl}$ and no evidence of atherosclerotic disease was present, as determined by histologic examination.

Two methods were used to examine Factor $\mathbf{X}_{\mathbf{a}}$-catalyzed prothrombin activation by atherosclerotic aortic segments. In one study, vessel segments were placed in a template device to conduct incubations; in the other method, an intact aortic arch was obtained and the reactions were conducted within the aortic lumen. Fig. 1 depicts a typical time course of thrombin generation by control and atherosclerotic vessels in the template device. Incubation mixtures included purified prothrombin, Factor $\mathbf{X}_{\mathrm{a}}$, and calcium. Typically, prothrombin activation by atherosclerotic vessels was enhanced eight- to ninefold over that produced by control vessels. Omission of Factor $X_{\mathrm{a}}$ or substitution of the zymogen, Factor $\mathrm{X}$, resulted in a failure of the vessel segments to activate prothrombin. Thus, prothrombin activation by atherosclerotic vessels occurred via the Factor $\mathrm{V}_{\mathrm{a}}$-Factor $\mathrm{X}_{\mathrm{a}}$ pathway, and not by an activator of Factor $\mathrm{X}$ or prothrombin.

Experiments with aortic arch segments were conducted to ensure that the enhanced prothrombin activation was not an artifact that resulted from placing the vessel segments flat in the template device. These aortic arch segments obtained from hypercholesterolemic animals also activated nine times more prothrombin than did control aortic arches (data not shown), which demonstrated that the enhanced prothrombin activation was not an artifact.

The duration of hypercholesterolemia required for enhanced aortic Factor $\mathbf{X}_{\mathrm{a}}$-catalyzed prothrombin activation was also investigated. In these studies, we measured Factor $X_{a}$-catalyzed prothrombin activation by aortic segments from rabbits on the diet for $5 \mathrm{~d}, 12 \mathrm{~d}, 4 \mathrm{wk}, 5 \mathrm{wk}$, and $6 \mathrm{wk}$. As in other experiments, vessel segments were selected from similar areas of the thoracic aorta. Aortic segments from some animals on the diet $4 \mathrm{wk}$ had visible fatty streaks, but they did not generate more thrombin than control segments. In contrast, after 5 wk of hypercholesterolemia, atherosclerotic vessels routinely exhibited increased prothrombinase activity.

In two rabbits that had been on the high-cholesterol diet for $14 \mathrm{wk}$, focal atherosclerotic lesions of the thoracic aorta were present instead of the diffuse lesions commonly observed. Assays of Factor $\mathrm{X}_{\mathrm{a}}$-catalyzed prothrombin activation by these aortic segments revealed increased activity only in involved areas; assays using what grossly appeared to be uninvolved aortic segments generated a level of thrombin very similar to that seen in control aortic segments. The inability to detect thrombin generation by vessel segments either from hypercholesterolemic animals on the diet for $<4$ wk or from focally uninvolved vessel segments may reflect insensitivity of our thrombin time assay to low concentrations of thrombin (the lower limit of detection was $\sim 0.5 \mathrm{U} / \mathrm{ml}$ ).

Experiments were also performed with segments of superior vena cava from control and hypercholesterolemic rabbits; atherosclerotic plaques were sometimes observed in this venous tissue of hypercholesterolemic rabbits. Factor $\mathbf{X}_{\mathrm{a}}$-catalyzed prothrombin activation by vena-caval segments was enhanced threefold compared with that seen with control venous segments.

Factor $V\left(V_{a}\right)$ activity of atherosclerotic aorta. Although our human anti-Factor V IgG could immunologically detect rabbit Factor V, it did not neutralize rabbit Factor V coagulant activity. Therefore, to correlate increased aortic Factor $\mathbf{X}_{\mathbf{a}}$-catalyzed prothrombin activation with vessel-wall Factor $\mathrm{V}$ activity, punch biopsy samples from control and atherosclerotic aortic segments were obtained from five rabbits of each group, and Factor $\mathrm{V}\left(\mathrm{V}_{\mathrm{a}}\right)$ activity was measured by clotting assay (Table I). Atherosclerotic segments were diffusely involved with lesion. Compared with control aortic segments, atherosclerotic aortic biopsy samples possessed approximately threeto fourfold more Factor $\mathrm{V}\left(\mathrm{V}_{\mathrm{a}}\right)$ activity; this increase was statistically significant $(P<0.05)$.

Previous studies with another atherogenic stimulus, homocysteine, indicated that activation of endogenous Factor $V$, and not increased cellular concentration of Factor V, was associated with enhanced Factor $\mathbf{X}_{\mathbf{a}}$-catalyzed prothrombin activation (4). To determine whether vessel-wall Factor $V$ was activated in the rabbit model of hypercholesterolemia, we studied the ability of Factor $\mathbf{X}_{\mathrm{a}}$ and control or hypercholesterolemic vessel segments to cleave ${ }^{125} \mathrm{I}$-prothrombin in an assay containing the thrombin inhibitor DAPA. The rationale for these experiments, based on earlier studies, is that prothrombin activation by endothelial cells and Factor $X_{a}$ requires thrombin to activate Factor V $(4,25)$. Fig. 2 is an autoradiogram demonstrating that with control aortic segments, Factor $\mathrm{X}_{\mathrm{a}}$ cleaved ${ }^{125} \mathrm{I}$-prothrombin in the absence of DAPA (left lane), but not in its presence (right lane). These data are similar to those obtained with normal cultured aortic endothelial cells (25). With atherosclerotic vascular tissue, Factor $X_{\mathbf{a}}$ cleaved more ${ }^{125}$ I-prothrombin than did control vascular tissue in the

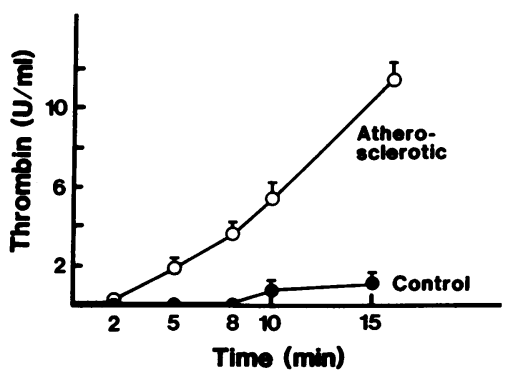

Figure 1. Time course of thrombin generation by Factor $\mathrm{X}_{\mathrm{a}}$ and either control or atherosclerotic aortic segments in the template device. Vessel-wall surface area was $\sim 0.75 \mathrm{~cm}^{2}$. Atherosclerotic segments were obtained from rabbits on the high-choles-

terol diet for 14 wk. Prothrombin activation was measured by incubating $70 \mu \mathrm{g}$ of prothrombin/ml and $20 \mathrm{ng}$ of Factor $X_{\mathrm{a}} / \mathrm{ml}$ in TBS containing $10 \mathrm{mM} \mathrm{CaCl}_{2}$. At intervals, aliquots were removed for assay of thrombin concentration. Each value represents the mean \pm SEM of three experiments.
Table I. Vessel-Wall Factor $V\left(V_{a}\right)$ Activity in Control and Atherosclerotic Segments*

\begin{tabular}{lc}
\hline Vessel segment & Factor $\mathrm{V}\left(\mathrm{V}_{\mathrm{a}}\right)$ activity \\
\hline & $m U / \mu g$ protein \\
Control & $0.08 \pm 0.02$ \\
Atherosclerotic & $0.28 \pm 0.05$ \\
\hline
\end{tabular}

* Control and atherosclerotic aortic punch biopsies $\left(\sim 1 \mathrm{~cm}^{2}\right)$ were obtained, placed in $0.5 \mathrm{ml}$ of TBS, and freeze-thawed before assay of Factor $\mathrm{V}\left(\mathrm{V}_{\mathrm{a}}\right)$ activity. Atherosclerotic samples were obtained from rabbits maintained on the high-cholesterol diet for 12-16 wk. Each value represents the mean \pm SEM of five experiments done on aortic segments of five rabbits. 


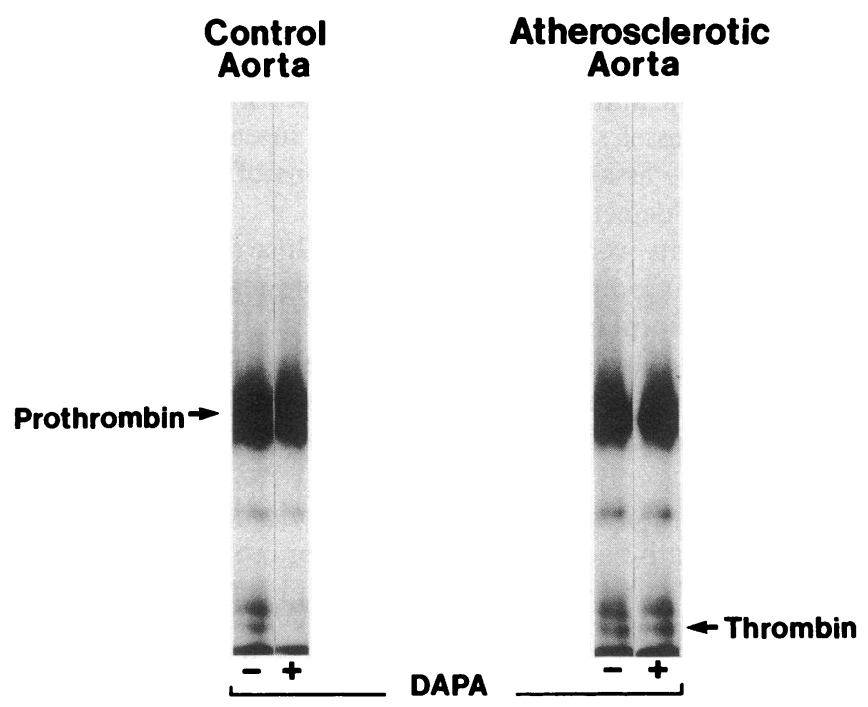

Figure 2. Cleavage of ${ }^{125} \mathrm{I}$-prothrombin by Factor $\mathrm{X}_{\mathrm{a}}$ and control or atherosclerotic aortic segments. ${ }^{125}$ I-Prothrombin activation was performed as described previously in the presence or absence of the thrombin inhibitor DAPA (25). Aliquots were obtained after $20 \mathrm{~min}$ and processed for nonreduced SDS-PAGE, which was followed by autoradiography. The autoradiogram of the dried gel is shown. The band just above thrombin represents an intermediate product of prothrombin activation (25).

absence of DAPA (left lane); however, Factor $\mathrm{X}_{\mathrm{a}}$ cleaved ${ }^{125} \mathrm{I}$ prothrombin in the presence of DAPA (right lane), suggesting that endogenous vascular Factor $\mathrm{V}$ is activated by a thrombinindependent mechanism.

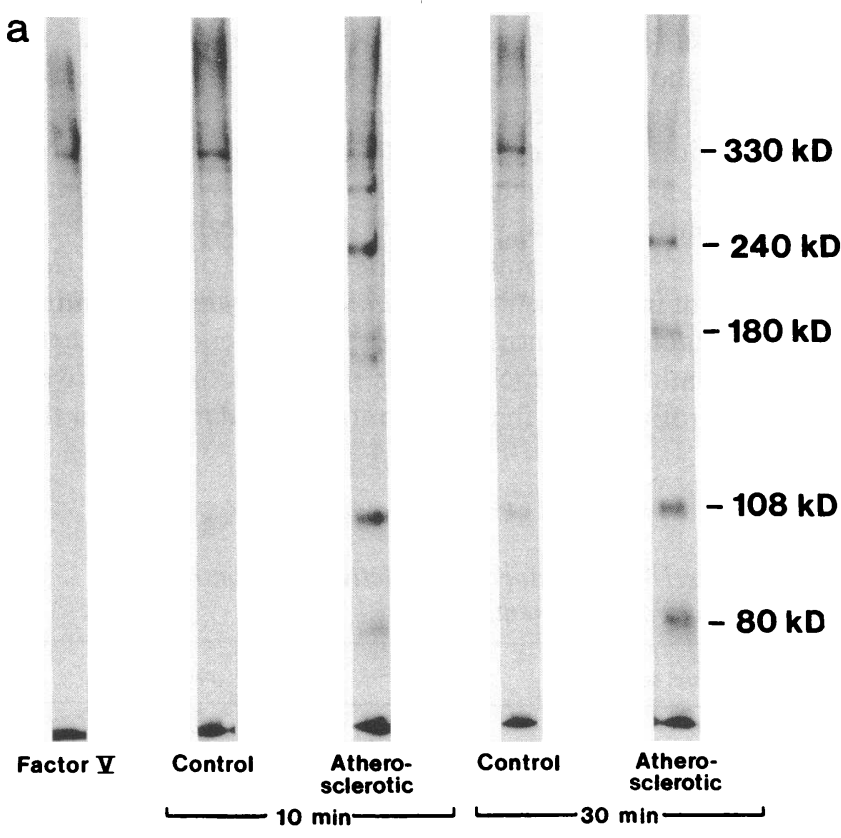

Figure 3. (A) Cleavage of ${ }^{125} \mathrm{I}$-Factor $\mathrm{V}$ by control and atherosclerotic aortic segments. $300 \mathrm{ng}$ of ${ }^{125} \mathrm{I}$-Factor $\mathrm{V} / \mathrm{ml}$ was incubated in DME that contained $1 \%$ BSA with $\sim 1 \mathrm{~cm}^{2}$ aortic segments obtained from control or hypercholesterolemic rabbits. At intervals, medium was removed and reduced SDS-gel buffer was added to the segments. Solubilized material associated with the vessel segments was analyzed by
To demonstrate directly the presence of a Factor $V$ activator in atherosclerotic aorta, ${ }^{125} \mathrm{I}$-Factor $\mathrm{V}$ was incubated with vessel segments obtained from control or hypercholesterolemic rabbits. As shown in Fig. $3 A$, significant cleavage of the single-chain protein resulted after incubation for 10 and 30 min with atherosclerotic but not with control vascular tissue. Prominent ${ }^{125} \mathrm{I}$-Factor $\mathrm{V}_{\mathrm{a}}$ peptides with apparent molecular weights of $240,000,180,000,108,000$, and 70,000-80,000 were observed. A comparison of the ${ }^{125} \mathrm{I}$-Factor $\mathrm{V}_{\mathrm{a}}$ peptides produced by homocysteine-treated cultured endothelial cells (4) is shown in Fig. $3 \mathrm{~B}$. The Factor $\mathrm{V}_{\mathrm{a}}$ peptides produced by both atherogenic stimuli had very similar molecular weights.

To determine the contribution of vascular endothelial cells to the increased vessel-wall Factor $\mathrm{V}$ activity, segments of control and atherosclerotic aorta were assayed for prothrombin activation before and after removal of the endothelium with a moist camel-hair brush. Removal of vascular endothelium from atherosclerotic aorta was associated with a $50 \%$ reduction in thrombin formation, while brushing of control vessel segments abolished thrombin formation (Fig. 4). Similar findings were observed in aortic segments obtained from three additional rabbits. Histologic examination of plastic-embedded sections made after the assays confirmed the removal of $\sim 95 \%$ of the endothelium by brushing and the retention of $\sim 80-90 \%$ of the endothelial cells in the nonbrushed segments (Fig. 5).

Immunocytochemical localization of Factor $V$ antigen in control and atherosclerotic aorta. The ability of Factor $\mathrm{X}_{\mathrm{a}}$ to activate prothrombin after the removal of most endothelial cells from atherosclerotic vessel segments suggested that Factor $\mathrm{V}\left(\mathrm{V}_{\mathrm{a}}\right)$-like activity might be associated with components of

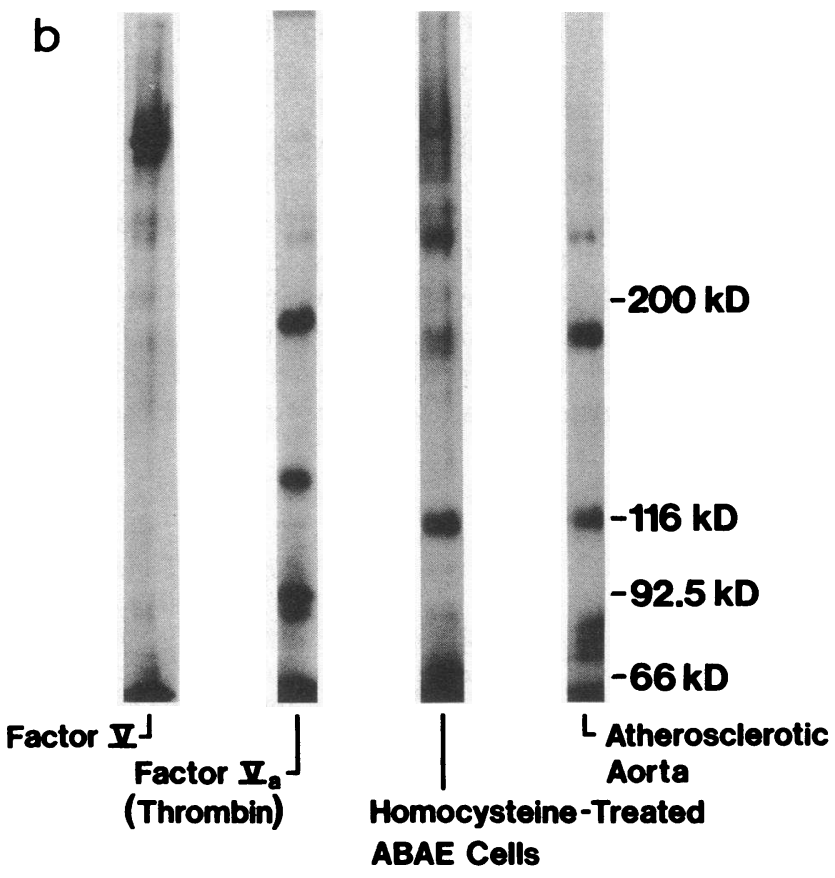

reduced SDS-PAGE and by autoradiography. The autoradiogram of the dried gel is shown. (B) Comparison of the ${ }^{125} \mathrm{I}-$ Factor $\mathrm{V}_{\mathrm{a}}$ peptides produced by atherosclerotic aorta or homocysteine-treated cultured endothelial cells. A Factor V standard and thrombin-generated Factor $\mathrm{V}$ are also depicted. 


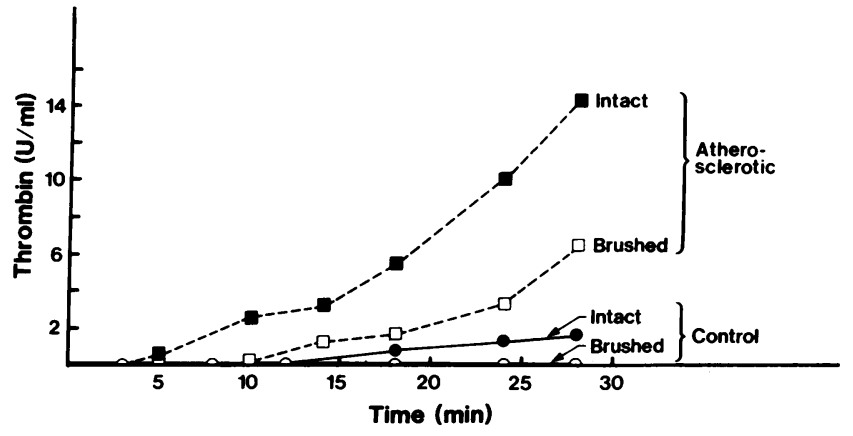

Figure 4. Reduction in vessel-wall Factor $\mathrm{X}_{\mathrm{a}}$-catalyzed prothrombin activation after removal of endothelium. Segments of control and atherosclerotic aortas were assayed for prothrombin activation before and after removal of endothelium with a moist camel-hair brush. Removal of endothelium from atherosclerotic aorta was associated with a $50 \%$ reduction in thrombin formation. Each value represents the mean of duplicate determinations. the blood vessel wall other than endothelial cells. To identify Factor $\mathrm{V}$ antigen in rabbit aortic tissue, it was first necessary to confirm the cross-reactivity of the anti-human Factor V IgG with rabbit Factor V. This was done with an immunoblot technique (Fig. 6), which clearly demonstrated that the antihuman Factor V IgG cross-reacted with rabbit Factor V. To assess the distribution of Factor $\mathrm{V}$ in atherosclerotic aorta, immunocytochemistry was performed using IgG from a patient with an autoantibody to Factor V. Factor V antigen (indicated as black peroxidase reaction product) was observed in both control (Fig. 7 B) and atherosclerotic aortic segments (Fig. $7 \mathrm{D}$ ). In control aorta, peroxidase reaction product was confined to the endothelium, whereas in atherosclerotic aorta, reaction product was also observed deeper within the intimal plaque. Preincubation of the anti-human Factor V IgG with purified human Factor $\mathrm{V}$ prevented the peroxidase reaction in both control and atherosclerotic segments (Fig. 7, $A$ and $C$, respectively). (The hematoxylin counterstain results in promi-
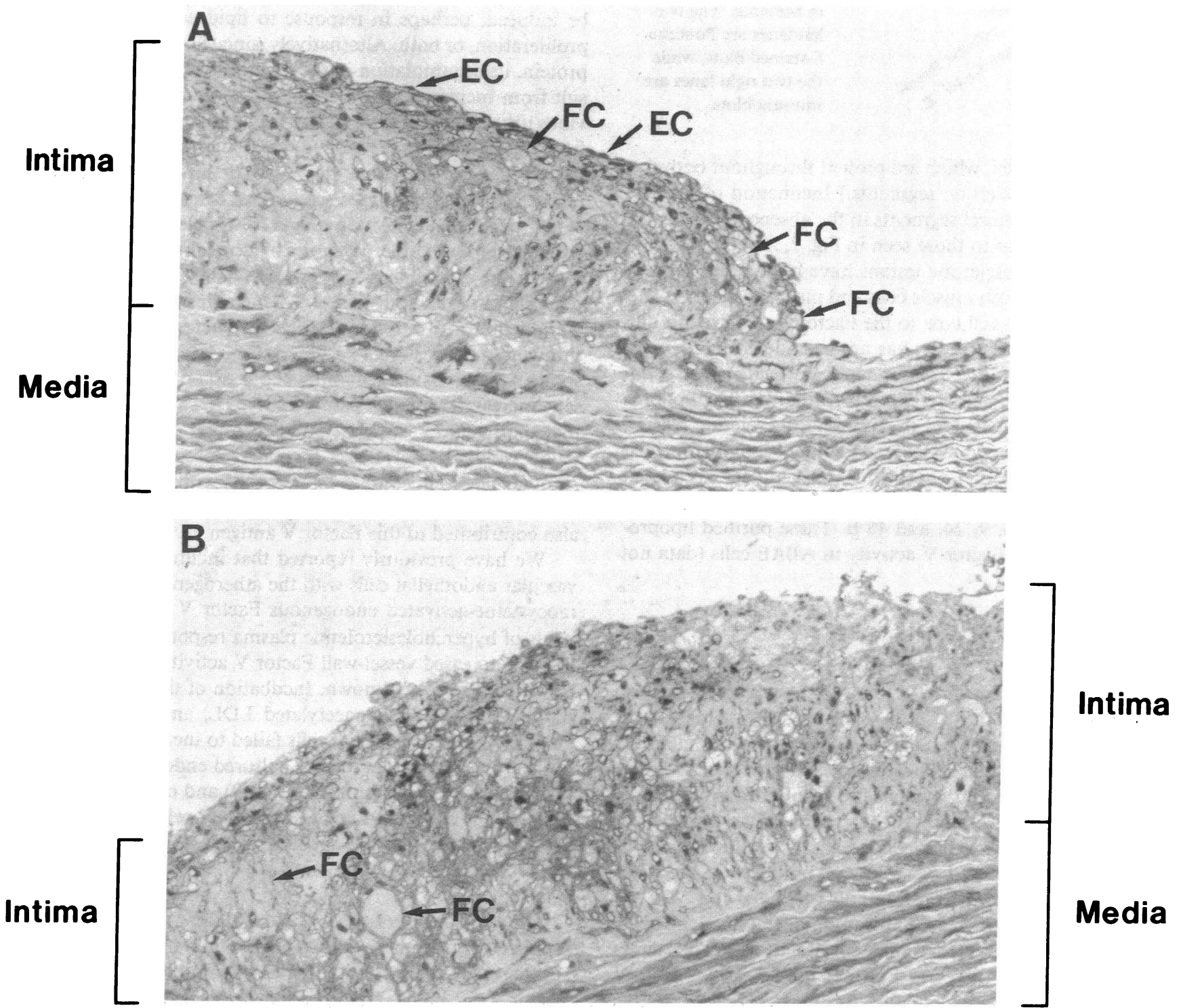

Figure 5. Photomicrographs of $2-\mu \mathrm{m}$, toluidine-stained, plastic-embedded atherosclerotic aortic sections after prothrombin activation assays. After completion of the experiments described in Fig. 4, vessel segments were processed for histologic analysis as described under
Methods. $(A)$ Atherosclerotic aorta before brushing. (B) Atherosclerotic aorta with endothelium removed ("brushed"). $E C$, endothelial cell; $F C$, foam cell. $\times 150$. 


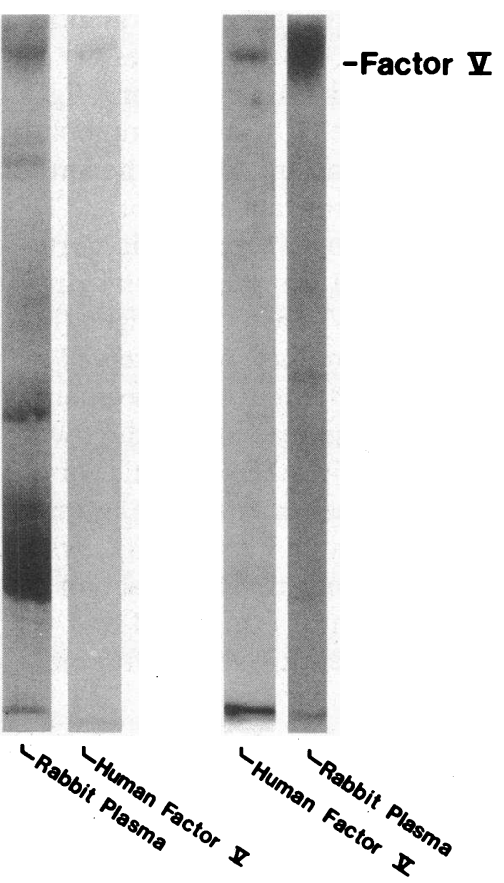

Figure 6. Demonstration of cross-reactivity of anti-human Factor V IgG with rabbit plasma Factor $\mathrm{V}$ by immunoblotting. $3 \mu \mathrm{g}$ of purified human Factor $\mathrm{V}$ and $3 \mu \mathrm{l}$ of normal rabbit plasma were subjected to nonreduced SDS-PAGE (5\%). Separated proteins were transferred to nitrocellulose filter paper and processed as described in Methods. The two left lanes are Ponceau S-stained blots, while the two right lanes are immunoblots.

nent staining of nuclei, which are present throughout both the control and atherosclerotic segments.) Incubation of control and atherosclerotic vessel segments in the absence of antibody yielded results similar to those seen in Fig. 7, $A$ and $C$, respectively. Rabbit atherosclerotic lesions have been demonstrated to contain both smooth muscle cells and macrophages (1). The contribution of each cell type to the Factor $\mathrm{V}$ observed in our immunocytochemistry studies has not been determined.

Effects of purified lipoproteins on adult bovine aortic endothelial cell Factor $V$ activity. To determine whether lipoproteins known to be increased in hypercholesterolemic plasma might mediate increased vessel-wall Factor $\mathrm{V}$ activity, purified native LDL and $\beta$-VLDL, as well as purified acetoacetylated LDL (5-60 $\mu \mathrm{g}$ of protein $/ \mathrm{ml}$ ), were incubated with cultured ABAE cells for $3,6,9,24$, and $48 \mathrm{~h}$. These purified lipoproteins did not affect Factor $V$ activity in ABAE cells (data not shown).

\section{Discussion}

The data in this report indicate that rabbit vascular tissue expresses Factor V activity. Both control and atherosclerotic aorta from hypercholesterolemic rabbits possessed Factor $\mathbf{V}$ activity, which resulted in Factor $\mathrm{X}_{\mathrm{a}}$-catalyzed prothrombin activation. Aorta from hypercholesterolemic animals expressed higher levels of activity than aorta from animals fed a normal diet. Increased Factor $\mathbf{X}_{\mathbf{a}}$-catalyzed prothrombin activation was first observed 4-5 wk after initiation of the highcholesterol diet. Aorta from animals on the diet 12-16 wk exhibited a ninefold increase in thrombin formation compared with control vessels. Punch biopsy specimens from atherosclerotic aorta yielded three- to fourfold increases in Factor $\mathrm{V}$ activity. One possible explanation for intact vessels exhibiting more coagulant activity than the punch biopsy samples might be that Factor $\mathrm{V}$ is a labile protein that may be inactivated during the freeze-thaw procedures used in the biopsy assays. Similar data were observed with cultured aortic endothelial cells treated with homocysteine; lysates of treated cells exhibited a fourfold increase in Factor $\mathrm{V}$ activity, while intact cells enhanced Factor $\mathrm{X}_{\mathrm{a}}$-catalyzed prothrombin activation 9- to 10-fold (4).

The Factor V in control vessels was associated with endothelial cells exclusively, as demonstrated by immunocytochemistry. In contrast, Factor $\mathrm{V}$ in atherosclerotic vessels was associated with both endothelial cells and cells deeper within the atherosclerotic lesion (presumably smooth muscle cells, macrophages, or both). There are reports that support the hypothesis that both macrophages and vascular smooth muscle cells may be responsible for Factor $\mathrm{V}$ staining in atherosclerotic lesions. Rothberger and McGee (36) have reported that rabbit alveolar macrophages secrete Factor $\mathrm{V}$, and one of the authors (G. M. Rodgers) has recently demonstrated that cultured vascular smooth muscle cells synthesize and secrete Factor V (37). Factor V antigen was not detected in smooth muscle cells of control vessels (Fig. 7). Therefore, the synthesis of Factor $\mathrm{V}$ in smooth muscle cells in atherosclerotic lesions must be induced, perhaps in response to lipid accumulation, cell proliferation, or both. Alternatively, since Factor $\mathrm{V}$ is a plasma protein, its accumulation in the atherosclerotic lesion may result from increased permeability of the vessel wall (38). Previous ultrastructural localization studies of IgG in aortic tissue from atherosclerotic rabbits (39) have suggested that increased permeability or filtration may account for a portion of the increased Factor $\mathrm{V}$ antigen seen in our experiments. Hansson et al. studied the deposition of IgG in vascular tissue of rabbits with diet-induced atherosclerosis by using immunohistochemistry at the electron microscopy level (39). Immunoreactive material was found only in the $5-8 \mu \mathrm{m}$ of lesion adjacent to the endothelium. In our studies (Fig. 7), Factor $\mathrm{V}$ was observed throughout the lesions to a depth of $\sim 1,400 \mu \mathrm{m}$. Therefore, some of the peroxidase staining in our experiments may represent increased vascular permeability. However, it is unlikely that the Factor $\mathrm{V}$ antigen found so much deeper within the lesion resulted solely from increased vascular permeability. Another possibility would be that cells within the atherosclerotic lesion (vascular smooth muscle cells and macrophages) also contributed to this Factor $\mathbf{V}$ antigen.

We have previously reported that incubation of cultured vascular endothelial cells with the atherogenic metabolite homocysteine-activated endogenous Factor V (4). The components of hypercholesterolemic plasma responsible for mediating the increased vessel-wall Factor $\mathrm{V}$ activity observed in the present study are unknown. Incubation of the atherogenic lipoproteins (LDL, acetoacetylated LDL, and $\beta$-VLDL) with cultured aortic endothelial cells failed to increase endogenous Factor V activity, even though cultured endothelial cells have receptors for these lipoproteins $(9,10)$ and even though these lipoproteins can be cytotoxic to cultured cells $(40,41)$. However, we cannot exclude a role for these lipoproteins in the increased expression of Factor $\mathrm{V}$ activity by atherosclerotic vessels.

The enhanced vascular Factor $\mathrm{V}$ activity and Factor $\mathrm{X}_{\mathrm{a}}$ catalyzed prothrombin activation seen in atherosclerotic vessel segments could result from increased amounts or activation of Factor V, or both. Both mechanisms have been found to account for increased Factor $\mathrm{V}$ activity of perturbed vascular endothelial cells. Annamalai et al. (42) reported that mechanical injury to human umbilical vein endothelial cells resulted in the expression or exposure of additional Factor $V$ antigen, and 


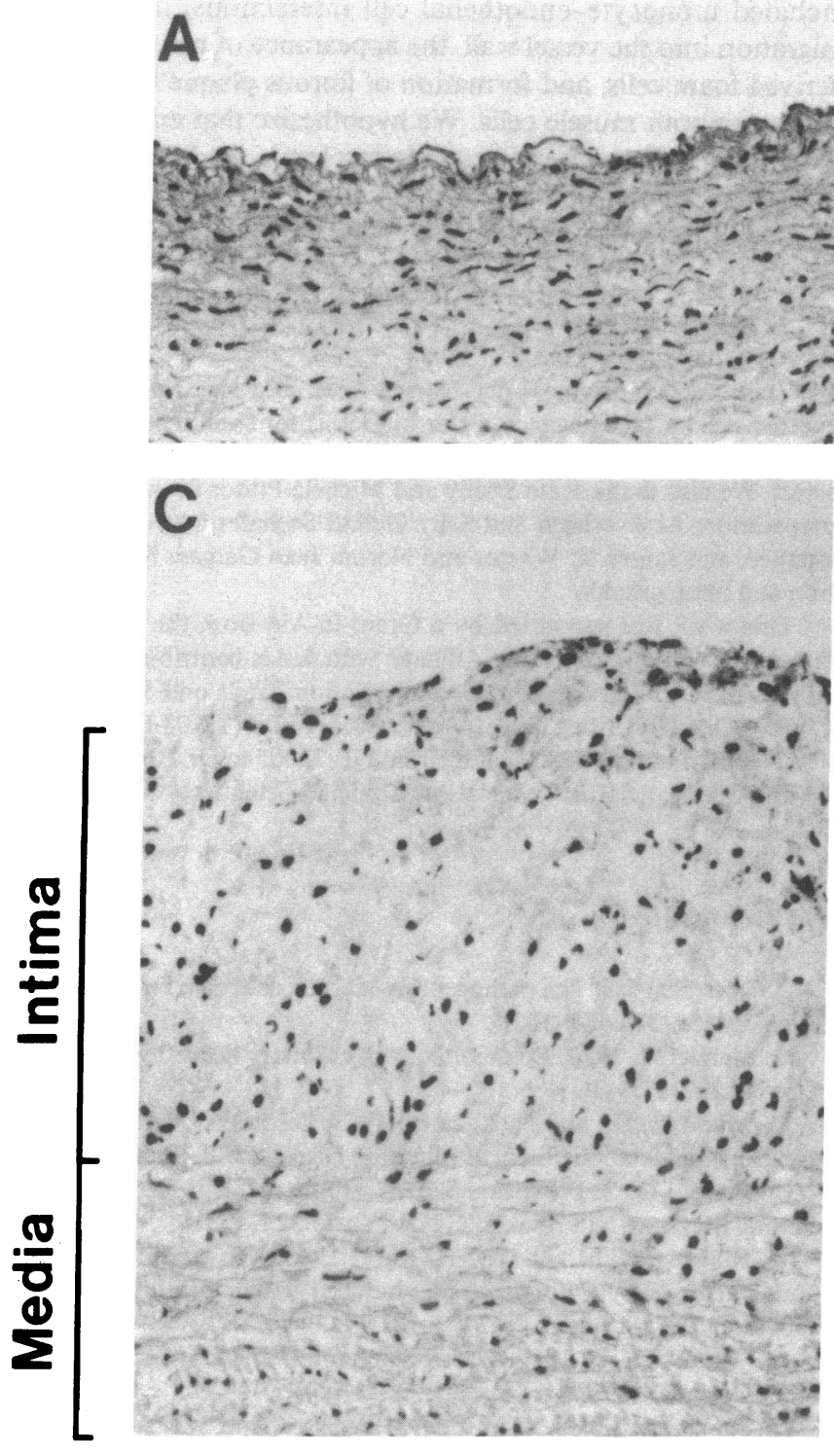

Figure 7. Photomicrographs of hematoxylin-stained control and atherosclerotic aorta showing the immunocytochemical localization of Factor $\mathrm{V}$ antigen. Aortic segments from control animals are shown in $A$ and $B$. Atherosclerotic aortic segments are shown in $C$ and $D$. The sections shown in $B$ and $D$ were incubated with an anti-Factor $\mathrm{V}$ IgG and processed to demonstrate the presence of Factor $\mathrm{V}$ (see

we described activation of endothelial cell Factor $\mathrm{V}$ by a homocysteine-induced vascular activator (4). The present data suggest that increased vessel-wall Factor $\mathrm{V}$ activity in hypercholesterolemic rabbits results from activation of endogenous Factor V. Although increased amounts of Factor V antigen were associated with cells within the atherosclerotic plaque, the importance of this source of Factor $V$ to overall vessel-wall Factor $\mathrm{V}$ activity is uncertain. In our studies and in reports by others (43), vascular endothelium remains essentially intact in this animal model. The possibility cannot be excluded that subendothelial expression of Factor $\mathrm{V}$ contributes to vesselwall Factor $\mathrm{X}_{\mathrm{a}}$-catalyzed prothrombin activation in this model. However, the ability of atherosclerotic vessel segments and Factor $X_{a}$ to cleave ${ }^{125} \mathrm{I}$-prothrombin in the presence of a thrombin inhibitor, and the cleavage of ${ }^{125} \mathrm{I}$-Factor $\mathrm{V}$ by ath-
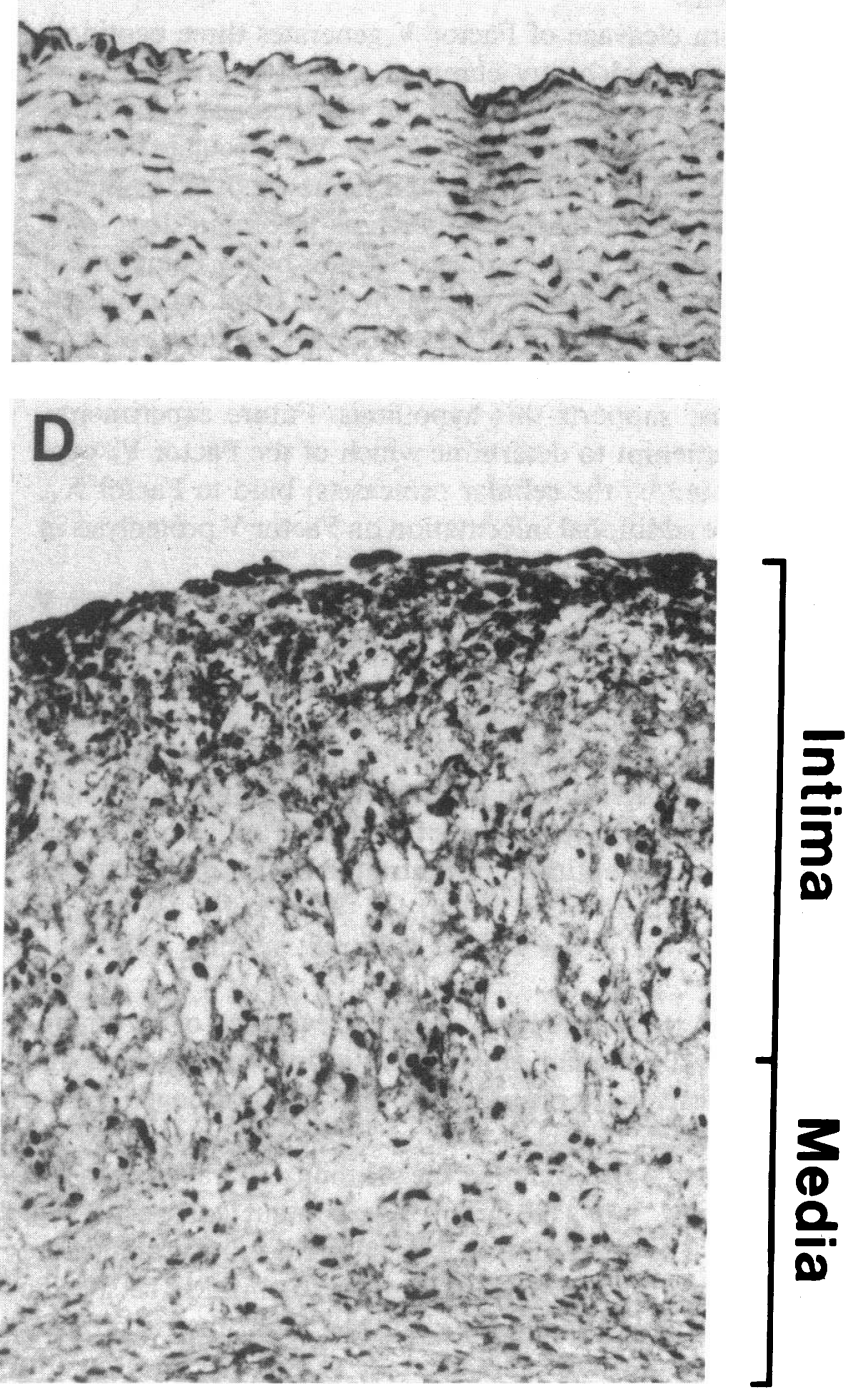

Methods). The sections shown in $A$ and $C$ were incubated with antiFactor V IgG that had been neutralized with purified Factor $V$. The only dark staining seen in $A$ and $C$ is due to hematoxylin staining of nuclei; in $B$ and $D$, both nuclei and Factor $\mathrm{V}$ immunoreaction product are visible. $\times 50$.

erosclerotic, but not by control vessel segments are more consistent with the hypothesis of Factor $\mathrm{V}$ activation. Nonetheless, both mechanisms may be operative in this model.

The ${ }^{125} \mathrm{I}$-Factor $\mathrm{V}_{\mathrm{a}}$ peptides produced by atherosclerotic aortic segments have apparent molecular weights very similar to those generated by homocysteine-treated aortic endothelial cells (Fig. $3 \mathrm{~B}$ ). These data suggest that both atherogenic stimuli, homocysteine and hypercholesterolemia, induce activation of Factor $\mathrm{V}$ by a similar mechanism, perhaps by a similar tissue protease. If this is the mechanism, previous studies with thrombin inhibitors in cultured endothelial cells (4), as well as the present data with DAPA (Fig. 2), indicate that this endothelial cell protease is not thrombin-like. The recent description of neutrophil-derived elastase that could activate Factor $\mathrm{V}$ (44), as well as the report of sulfhydryl protease activation of 
Factor V (45), suggests that there may be a variety of cellular proteases that are important in regulation of coagulation by perturbed cells.

Thrombin cleavage of Factor $\mathrm{V}$ generates three peptides: an amino-terminal heavy chain, a carboxyl-terminal light chain (both function as Factor $\mathrm{V}_{\mathrm{a}}$ in the presence of calcium ions), and an activation peptide $(22,46)$. We speculate that the cellular protease(s) found in vascular tissue exposed to atherogenic stimuli cleaves Factor $\mathrm{V}$ much as thrombin does, producing a Factor $\mathrm{V}_{\mathrm{a}}$ species consisting of a heavy chain and a light chain that differ in molecular weight from those generated by thrombin. The observation that a similar number of Factor $\mathrm{V}_{\mathrm{a}}$ peptides are generated by thrombin and by the cellular protease supports this hypothesis. Future experiments, which will attempt to determine which of the Factor $V_{a}$ peptides generated by the cellular protease(s) bind to Factor $X_{a}$, may provide additional information on Factor $\mathrm{V}$ proteolysis in our model.

In the hypercholesterolemic animals, increased Factor $\mathrm{V}$ activity may lead to increased production of thrombin. Increased amounts of thrombin may contribute to atherogenesis, since thrombin has been shown to be both chemotactic and mitogenic for monocytes $(13,14)$. Thrombin has also been shown to cause endothelial cell retraction (15) and generation of platelet-derived growth factor (PDGF)-like mitogenic activity (16). The optimal concentration of thrombin required for these effects is $1-10 \mathrm{nM}(0.1-1 \mathrm{U} / \mathrm{ml})(13,14,16)$, an amount that the vessel wall or cultured vascular cells could generate (27).

Other investigators have observed evidence of thrombinlike activity in human atherosclerotic lesions. Shainoff and Page described the deposition of a modified fibrinogen species within the aortic intima of atherosclerotic vascular tissue (47). This modified fibrinogen had the solubility characteristics of a stabilized clot, but a fibrinopeptide content consistent with fibrinogen. The exact nature of this protein is uncertain. More recently, immunocytochemistry studies using MAbs specific for fibrin determinants have identified fibrin that is presumably derived from thrombin cleavage of fibrinogen within atherosclerotic human vascular tissue (48).

In the initial response-to-injury hypothesis (49), Ross and Harker proposed that the atherosclerotic lesion resulted from smooth muscle cell proliferation; this hypothesis required PDGF secretion from platelets adherent to denuded endothelium. However, such denuding endothelial cell injuries have not been demonstrated to occur before the development of the atherosclerotic lesion. A recent modification of this hypothesis (1) proposed that subtler endothelial cell perturbation is sufficient to initiate atherogenesis. In this model, perturbed endothelial cells would secrete PDGF, initiating smooth muscle cell proliferation (1). Our data would be compatible with this mechanism, in that thrombin generation resulting from perturbed endothelium may be sufficient to initiate mitogen secretion and other critical events in atherogenesis.

Although there are differences in the pathogenesis of atherosclerosis in animal models and humans $(17,18,50,51)$, the hypercholesterolemic rabbit model shares several features with the human vascular disorder. As recently reviewed by Ross (1), examination of atherosclerotic lesions from several animal models, including hypercholesterolemic rabbits, revealed a cellular composition and histologic pattern similar to that observed in vessels from affected patients (52). These similarities included monocyte-endothelial cell interactions, monocyte migration into the vessel wall, the appearance of macrophagederived foam cells, and formation of fibrous plaque by proliferating smooth muscle cells. We hypothesize that endothelial cell injury induced by hypercholesterolemia leads to expression of vessel-wall procoagulant (Factor $V$ ) activity that may mediate many of these events.

\section{Acknowledgments}

We acknowledge Regina Lim, Donna Foss, and Jim McGuire for excellent technical assistance, Peter Lindquist for assistance with animal care and surgery, and Dr. David Phillips for reviewing the manuscript. We also thank Kate Sholly and Michele Prator for manuscript preparation, Al Averbach and Sally Gullatt Seehafer for editorial assistance, and James X. Warger and Norma Jean Gargasz for illustration and photography.

This work was supported by a Grant-in-Aid from the American Heart Association, California Affiliate; with funds contributed by the American Heart Association, Central Mission Trails and San Mateo County Chapters; by a Clinical Investigator Award (1 K08 HL-01031) and National Institutes of Health Grant HL-33005 to Dr. Rodgers; and by an American Heart Association Clinician-Scientist Award to Dr. Kane.

\section{References}

1. Ross, R. 1986. The pathogenesis of atherosclerosis: an update. $N$. Engl. J. Med. 314:488-500.

2. Stamler, J. 1973. Epidemiology of coronary heart disease. Med. Clin. N. Am. 57:5-46.

3. Mudd, S. H., and H. L. Levy. 1983. Disorders of transsulfuration. In The Metabolic Basis of Inherited Disease. J. B. Stanbury, J. B. Wyngaarden, D. S. Fredrickson, J. L. Goldstein, and M. S. Brown, editors. McGraw-Hill Book Co., New York. 522-559.

4. Rodgers, G. M., and W. H. Kane. 1986. Activation of endogenous Factor $\mathbf{V}$ by a homocysteine-induced vascular endothelial cell activator. J. Clin. Invest. 77:1909-1916.

5. Mann, K. G. 1984. Membrane-bound enzyme complexes in blood coagulation. Prog. Hemostasis Thromb. 7:1-23.

6. Rapaport, S. I., S. Schiffman, M. J. Patch, and S. B. Ames. 1963. The importance of activation of antihemophilic globulin and proaccelerin by traces of thrombin in the generation of intrinsic prothrombinase activity. Blood. 21:221-236.

7. Rodman, N. F., S. N. Jagannathan, J. J. Jenkins III, J. A. Rodman, and P. A. Allender. 1979. Experimental atherosclerosis: surface ultrastructural studies in the rabbit aorta. Scanning Electron Microsc. III:835-841.

8. Ingerman-Wojenski, C. M., A. W. Sedar, M. Nissenbaum, M. J. Silver, D. M. Klurfeld, and D. Kritchevsky. 1983. Early morphological changes in the endothelium of a peripheral artery of rabbits fed an atherogenic diet. Exp. Mol. Pathol. 38:48-60.

9. Stein, O., and Y. Stein. 1980. Bovine aortic endothelial cells display macrophage-like properties towards acetylated ${ }^{125}$ I-labelled low density lipoprotein. Biochim. Biophys. Acta. 620:631-635.

10. Baker, D. P., B. J. Van Lenten, A. M. Fogelman, P. A. Edwards, C. Kean, and J. A. Berliner. 1984. LDL, scavenger, and $\beta$-VLDL receptors on aortic endothelial cells. Arteriosclerosis: 4:248-255.

11. Colucci, M., G. Balconi, R. Lorenzet, A. Pietra, D. Locati, M. B. Donati, and N. Semeraro. 1983. Cultured human endothelial cells generate tissue factor in response to endotoxin. J.' Clin. Invest. 71:1893-1896.

12. Bevilacqua, M. P., J. S. Pober, G. R. Majeau, R. S. Cotran, and M. A. Gimbrone, Jr. 1984. Interleukin-1 (IL-1) induces biosynthesis and cell surface expression of procoagulant activity in human vascular endothelial cells. J. Exp. Med. 160:618-623. 
13. Bar-Shavit, R., A. Kahn, J. W. Fenton II, and G. D. Wilner. 1983. Chemotactic response of monocytes to thrombin. J. Cell Biol. 96:282-285.

14. Bar-Shavit, R., A. Kahn, K. G. Mann, and G. D. Wilner. 1986. Identification of a thrombin sequence with growth factor activity on macrophages. Proc. Natl. Acad. Sci. USA. 83:976-980.

15. Laposata, M., D. K. Dovnarsky, and H. S. Shin. 1983. Thrombin-induced gap formation in confluent endothelial cell monolayers in vitro. Blood. 62:549-556.

16. Harlan, J. M., P. J. Thompson, R. R. Ross, and D. F. BowenPope. 1986. $\alpha$-Thrombin induces release of platelet-derived growth factor-like molecule(s) by cultured human endothelial cells. J. Cell Biol. 103:1129-1133.

17. Vesselinovitch, D., and R. W. Wissler. 1977. Comparison of primates and rabbits as animal models in experimental atherosclerosis. Adv. Exp. Med. Biol. 82:614-622.

18. Jokinen, M. P., T. B. Clarkson, and R. W. Prichard. 1985. Animal models in atherosclerosis research. Exp. Mol. Pathol. 42:1-28.

19. Faggiotto, A., R. Ross, and L. Harker. 1984. Studies of hypercholesterolemia in the nonhuman primate. I. Changes that lead to fatty streak formation. Arteriosclerosis. 4:323-340.

20. Faggiotto, A., and R. Ross. 1984. Studies of hypercholesterolemia in the nonhuman primate. II. Fatty streak conversion to fibrous plaque. Arteriosclerosis. 4:341-356.

21. Miletich, J. P., G. J. Broze, Jr., and P. W. Majerus. 1980. The synthesis of sulfated dextran beads for isolation of human plasma coagulation Factors II, IX, and X. Anal. Biochem. 105:304-310.

22. Kane, W. H., and P. W. Majerus. 1981. Purification and characterization of human coagulation Factor V. J. Biol. Chem. 256:1002-1007.

23. Bradford, M. M. 1976. A rapid and sensitive method for the quantitation of microgram quantities of protein utilizing the principle of protein-dye binding. Anal. Biochem. 72:248-254.

24. Bachmann, F., F. Duckert, and F. Koller. 1958. The StuartPrower factor assay and its clinical significance. Thromb. Diath. Haemorrh. 2:24-38.

25. Rodgers, G. M., and M. A. Shuman. 1983. Prothrombin is activated on vascular endothelial cells by Factor $\mathrm{X}_{\mathrm{a}}$ and calcium. Proc. Natl. Acad. Sci. USA. 80:7001-7005.

26. Rouleau, J.-L., W. W. Parmley, J. Stevens, J. Wikman-Coffelt, R. Sievers, R. W. Mahley, and R. J. Havel. 1983. Verapamil suppresses atherosclerosis in cholesterol-fed rabbits. J. Am. Coll. Cardiol. 1:1453-1460.

27. Rodgers, G. M., and M. A. Shuman. 1985. Characterization of the interaction between Factor $\mathbf{X}_{\mathbf{a}}$ and bovine aortic endothelial cells. Biochim. Biophys. Acta. 844:320-329.

28. Fenton, J. W., II, and M. J. Fasco. 1974. Polyethylene glycol 6,000 enhancement of the clotting of fibrinogen solutions in visual and mechanical assays. Thromb. Res. 4:809-817.

29. Towbin, H., T. Staehelin, and J. Gordon. 1979. Electrophoretic transfer of proteins from polyacrylamide gels to nitrocellulose sheets: procedure and some applications. Proc. Natl. Acad. Sci. USA. 76:4350-4354.

30. Salinovich, O., and R. C. Montelaro. 1986. Reversible staining and peptide mapping of proteins transferred to nitrocellulose after separation by sodium dodecyl sulfate-polyacrylamide gel electrophoresis. Anal. Biochem. 156:341-347.

31. Boyles, J., R. E. Pitas, E. Wilson, R. W. Mahley, and J. M. Taylor. 1985. Apolipoprotein E associated with astrocytic glia of the central nervous system and with nonmyelinating glia of the peripheral nervous system. J. Clin. Invest. 76:1501-1513.

32. Beckstead, J. H., P. S. Halverson, C. A. Ries, and D. F. Bainton. 1981. Enzyme histochemistry and immunohistochemistry on biopsy specimens of pathologic human bone marrow. Blood. 57:1088-1098.

33. Lewis, M. L., and A. G. Ware. 1953. A one stage method for the determination of accelerator globulin. Proc. Soc. Exp. Biol. Med. 84:640-643.

34. Pitas, R. E., T. L. Innerarity, and R. W. Mahley. 1980. Cell surface receptor binding of phospholipid - protein complexes containing different ratios of receptor-active and -inactive $\mathrm{E}$ apoprotein. $J$. Biol. Chem. 255:5454-5460.

35. Pitas, R. E., T. L. Innerarity, J. N. Weinstein, and R. W. Mahley. 1981. Acetoacetylated lipoproteins used to distinguish fibroblasts from macrophages in vitro by fluorescence microscopy. Arteriosclerosis. 1:177-185.

36. Rothberger, H., and M. P. McGee. 1984. Generation of coagulation Factor $\mathrm{V}$ activity by cultured rabbit alveolar macrophages. $J$. Exp. Med. 160:1880-1890.

37. Rodgers, G. M. 1988. Vascular smooth muscle cells synthesize, secrete and express coagulation Factor V. Biochim. Biophys. Acta. 968:17-23.

38. Björkerud, S., and G. Bondjers. 1972. Endothelial integrity and viability in the aorta of the normal rabbit and rat as evaluated with dye exclusion tests and interference contrast microscopy. Atherosclerosis. 15:285-300.

39. Hansson, G. K., G. Bondjers, A. Bylock, and L. Hjalmarsson. 1980. Ultrastructural studies on the localization of IgG in the aortic endothelium and subendothelial intima of atherosclerotic and nonatherosclerotic rabbits. Exp. Mol. Pathol. 33:302-315.

40. Henriksen, T., S. A. Evensen, and B. Carlander. 1979. Injury to human endothelial cells in culture induced by low density lipoproteins. Scand. J. Clin. Lab. Invest. 39:361-368.

41. Morel, D. W., J. R. Hessler, and G. M. Chisolm. 1983. Low density lipoprotein cytotoxicity induced by free radical peroxidation of lipid. J. Lipid Res. 24:1070-1076.

42. Annamalai, A. E., G. J. Stewart, B. Hansel, M. Memoli, H.-C. Chiu, D. W. Manuel, K. Doshi, and R. W. Colman. 1986. Expression of Factor $\mathrm{V}$ on human umbilical vein endothelial cells is modulated by cell injury. Arteriosclerosis. 6:196-202.

43. Walker, L. N., M. A. Reidy, and D. E. Bowyer. 1986. Morphology and cell kinetics of fatty streak lesion formation in the hypercholesterolemic rabbit. Am. J. Pathol. 125:450-459.

44. Oates, A. M., and H. H. Salem. 1987. The regulation of human Factor $\mathrm{V}$ by a neutrophil protease. Blood. 70:846-851.

45. Rodgers, G. M., J. Cong, D. Goll, and W. H. Kane. 1987. Activation of coagulation Factor $\mathrm{V}$ by the calcium-dependent proteinase. Biochim. Biophys. Acta. 929:263-270.

46. Nesheim, M. E., and K. G. Mann. 1979. Thrombin-catalyzed activation of single chain bovine Factor V. J. Biol. Chem. 254:13261334.

47. Shainoff, J. R., and I. H. Page. 1972. Deposition of modified fibrinogen within the aortic intima. Atherosclerosis. 16:287-305.

48. Bini, A., J. Fenoglio, Jr., J. Sobel, J. Owen, M. Fejgl, and K. L. Kaplan. 1987. Immunochemical characterization of fibrinogen, fibrin I, and fibrin II in human thrombi and atherosclerotic lesions. Blood. 69:1038-1045.

49. Ross, R., and L. Harker. 1976. Hyperlipidemia and atherosclerosis. Chronic hyperlipidemia initiates and maintains lesions by endothelial cell desquamation and lipid accumulation. Science (Wash. DC). 193:1094-1100.

50. Guski, H., R. Meyer, G. Wassilew, K. Wenzelides, and K. Wilfert. 1981. Characterization of the rabbit heart in cholesterol-induced coronary atherosclerosis. Morphometric studies. Exp. Pathol. (Jena). 19:100-111.

51. Wissler, R. W., and D. Vesselinovitch. 1968. Experimental models of human atherosclerosis. Ann. NY Acad. Sci. 149:907-922.

52. Ross, R., T. N. Wight, E. Strandness, and B. Thiele. 1984. Human atherosclerosis. I. Cell constitution and characteristics of advanced lesions of the superficial femoral artery. Am. J. Pathol. 114:79-93. 